\title{
Risks of endemicity, morbidity and perspectives regarding the control of Chagas disease in the Amazon Region
}

\author{
José Rodrigues Coura/ ${ }^{+}$, Angela CV Junqueira \\ Laboratório de Doenças Parasitárias, Instituto Oswaldo Cruz-Fiocruz, Av. Brasil 4365, 21040-360 Rio de Janeiro, RJ, Brasil
}

\begin{abstract}
Chagas disease, in the Amazon Region as elsewhere, can be considered an enzootic disease of wild animals or an anthropozoonosis, an accidental disease of humans that is acquired when humans penetrate a wild ecosystem or when wild triatomines invade human dwellings attracted by light or searching for human blood. The risk of endemic Chagas disease in the Amazon Region is associated with the following phenomena: (i) extensive deforestation associated with the displacement of wild mammals, which are the normal sources of blood for triatomines, (ii) adaptation of wild triatomines to human dwellings due to the need for a new source of blood for feeding and (iii) uncontrolled migration of human populations and domestic animals that are already infected with Trypanosoma cruzi from areas endemic for Chagas disease to the Amazon Region. Several outbreaks of severe acute cases of Chagas disease, as well as chronic cases, have been described in the Amazon Region. Control measures targeted to avoiding endemic Chagas disease in the Amazon Region should be the following: improving health education in communities, training public health officials and communities for vector and Chagas disease surveillance and training local physicians to recognise and treat acute and chronic cases of Chagas diseases as soon as possible.
\end{abstract}

Key words: Chagas disease - risks of endemicity - morbidity - Amazon Region - control perspectives

The entire Amazon Region, or "Pan-Amazonia", has more than 30 million inhabitants, covers $44 \%$ of the South American landmass and extends through nine countries: Bolivia, Brazil, Colombia, Ecuador, Guyana, French Guiana, Peru, Suriname and Venezuela, as shown on the map in Fig. 1.

The Brazilian Amazon Region covers 4,871,500 km², accounting for $67 \%$ of the $7,275,300 \mathrm{~km}^{2}$ of Pan-Amazonia (Table I). Pan-Amazonia not only has natural wealth due to its enormous biodiversity and major oil and gas reserves, but also contains $20 \%$ of all the freshwater in the world. This may be the greatest measure of wealth in the future, given the freshwater scarcities the world is currently experiencing. Similarly, Pan-Amazonia contains for one-third of the world's broad-leafed forests (Castro 1998). Despite the region's low human population density, which shows large variation among its nine countries, its greatest problems are disorderly occupation, uncontrolled deforestation and the notoriously covetous manner in which the region is regarded internationally, precisely because of its biodiversity and natural wealth.

With respect to the Brazilian national territory, the Amazon Region occupies approximately 58\% of the country and falls within the boundaries of nine states: Acre (AC), Amapá (AP), Amazonas (AM), Maranhão (MA), Mato Grosso (MT), Rondônia, Roraima (RR), Pará (PA) and Tocantins (TO). The Brazilian Amazon Region portrays the wealth and problems of Pan-Ama-

Financial support: CNPq (471716/2009-0)

+ Corresponding author: coura@ioc.fiocruz.br

Received 22 December 2011

Accepted 1 February 2012 zonia intensified, encompassing the largest river complex in the world, the largest sedimentary basin on the planet and the greatest ecosystem and biodiversity in the biosphere. The Brazilian Amazon Region has enormous potential in terms of the energy balance of light and heat. It has been estimated than every square centimetre of the region releases 420 calories/day (Branco 1990), though harnessing, storing and transmitting the naturally released energy for human use remains impossible with present-day technology. However, in addition to the major problems of Pan-Amazonia noted above (disorderly occupation, uncontrolled deforestation, risk of desertification and international covetousness), on a much larger scale, the Brazilian Amazon Region is characterised by difficulties related to health promotion and healthcare because of the lack of qualified professionals, the dispersion of the population over wide areas and the lack of infrastructure for medical care.

Many diseases are endemic in the Brazilian Amazon Region. Prominent among these diseases are malaria, American cutaneous leishmaniasis, several arboviruses, tuberculosis, leprosy, infectious diarrhoea, intestinal parasitosis and other diseases that are also frequently found in other regions of Brazil. More recently, dengue, which re-entered Brazil through RR in 1982, has produced epidemics in the Amazon Region, similar to what has been observed in several other Brazilian states, including the epidemic caused by the entry of type 4 dengue into that state. In contrast, Chagas disease, which is the main topic of this review, is thought to have existed in the Amazon Region for millions of years as an enzootic disease of wild animals. However, the first human cases were not diagnosed until 1941 in French Guiana (Floch \& Tasque 1941, Floch \& Camain 1948) and 1969 in the Brazilian Amazon Region (Shaw et al. 1969). 


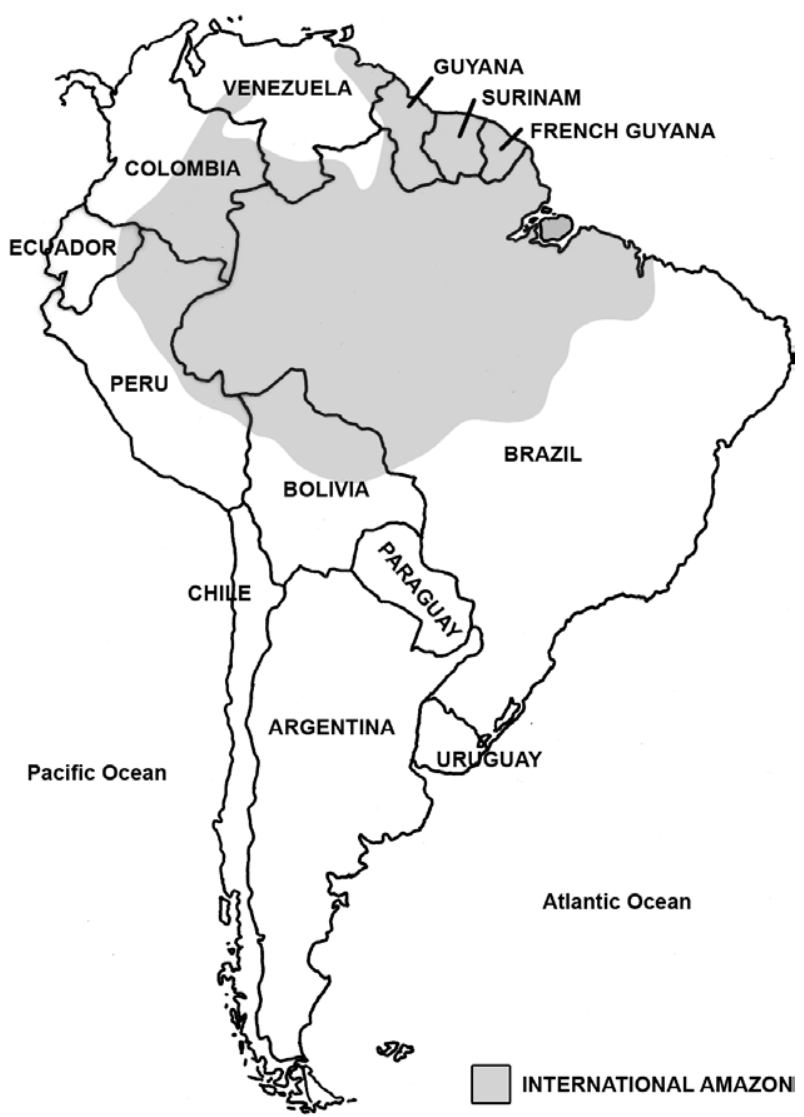

Fig. 1: location of Amazon Region in South America.

The aim of this review was to analyse the current situation regarding Chagas disease in the Amazon Region and the risk of endemicity for the region as well as to propose health promotion and disease prevention measures. The characteristics of this disease are highly diverse in this region when compared to other endemic areas of Chagas disease in Latin America.

The current situation regarding Chagas disease in the Amazon - Chagas disease in Pan-Amazonia can, overall, be considered to be an enzootic disease of wild animals, given that the foci of wild triatomines that are pre-adapted to human peridomestic environments have only been reported in extremely rare localities. In such situations, the insects feed off domestic animals and poultry as well as wild animals, such as marsupials, that approach and invade homes in their search for food (Coura et al. 1999, 2002b). With respect to human infection, Chagas disease in Pan-Amazonia can be considered to be an anthropozoonosis, i.e., an accidental disease in humans, which is acquired when humans penetrate the wild ecosystem to hunt, gather plant material or undertake tourist activities, among other reasons. Chagas disease can also occur when wild triatomines invade human homes attracted by the light or in search of food in the form of human blood, although this usually occurs in the absence of wild mammals (Coura 1988, Coura et al. 2007). Contamination of

\section{TABLE I}

Amazon area and the percentage occupied by each country

\begin{tabular}{lcc}
\hline Countries & $\begin{array}{c}\text { Amazon Region } \\
\left(\mathrm{Km}^{2}\right)\end{array}$ & $\begin{array}{c}\text { Amazon area } \\
(\%)\end{array}$ \\
\hline Brazil & 4.871 .5 & 57.23 \\
Peru & 764.2 & 59.45 \\
Colombia & 504.6 & 44.28 \\
Bolivia & 391.6 & 35.61 \\
Venezuela & 175.7 & 19.18 \\
Ecuador & 128.7 & 47.05 \\
Guyana & 215 & 97 \\
Surinam & 143 & 100 \\
French Guiana & 81 & 100 \\
\hline Total & 7.275 .3 & 44 \\
\hline
\end{tabular}

source: Aguilar et al. (2007).

uncooked foods by the faeces and urine of wild triatomines or by the scent secretions of Didelphis marsupialis, which can host infective forms of Trypanosoma cruzi, is of great importance regarding human infection in PanAmazonia (Deane et al. 1984, Coura 2006, 2007). At least 27 species belonging to nine genera of triatomines have already been observed in Pan-Amazonia (AbadFranch \& Monteiro 2007) and the great majority of these species are naturally infected with $T$. cruzi. Similarly, the enormous fauna of wild mammals infected by T. cruzi in this region (Deane \& Jansen 1939, Deane 1961, 1964a, b, 1967, Deane \& Damasceno 1961, Barretto 1964, 1967) demonstrates that there is a large reservoir of T. cruzi in the Amazon Region, thus maintaining the infection cycle in this region.

As mentioned earlier, the first human cases of Chagas disease reported in the Amazon Region were reported by Floch and Tasque (1941) and Floch and Camain (1948) in French Guiana. More than 20 years later, additional cases were reported by Shaw et al. (1969) in Belém, PA in the Brazilian Amazon Region. Since that time, nearly all countries within Pan-Amazonia have reported acute cases of Chagas disease, particularly Brazil (Coura et al. 1993, 1994a, b, 1995a, b, 1999, 2002a, b, 2007, Valente \& Valente 1993, Valente et al. 1994, 1998, 1999, 2000, 2009, Aguilar et al. 2007, Pinto et al. 2008, Coura \& Dias 2009, Brum-Soares et al. 2010).

Chagas disease in the Brazilian Amazon - As in Pan-Amazonia overall, Chagas disease in the Brazilian Amazon Region had always been considered to be an enzootic disease of wild animals until Shaw et al. (1969) described the first four cases of human infection with $T$. cruzi in Belém from a small outbreak most likely caused by oral transmission. More recently, Pinto et al. (2008) studied 233 acute cases of the disease that had been observed between 1968-2005 at the Evandro Chagas Institute in PA. These patients had come from PA, AP and MA. Most cases $(78.5 \%, 183 / 233)$ were associated with outbreaks, most likely occurring through oral transmis- 
sion, while $21.5 \%(56 / 233)$ had occurred as isolated acute cases. Initially, these authors examined 430 cases of acute Chagas disease from this institution. However, only 233 cases were studied because 197 cases did not fulfil the criteria for acute cases, i.e., showing the presence of $T$. cruzi in direct fresh-sample examination, in stained thick blood smears or using concentration methods, such as Strout and quantitative buffy coat. This was the largest sample of acute cases of Chagas disease assembled to date after that included in the study by Laranja et al. (1956) in Bambuí, Minas Gerais (MG). Moreover, the notification rate for acute cases in the Brazilian Amazon Region has been increasing exponentially. Between 1969-2008, the Health Surveillance Department of the Ministry of Health reported a total of 761 cases, of which $75 \%$ (568 cases) occurred between 2002-2008 (Brum-Soares et al. 2010).

The national serological survey conducted by the Campaign Superintendence of the Ministry of Health between 1975-1980 (Camargo et al. 1984) revealed that the mean prevalence for Chagas disease in Brazil was $4.2 \%$ and that the highest rates observed were in the states of Rio Grande do Sul (8.8\%), MG (8.8\%), Goiás (7.4\%), Alagoas (6\%), Bahia (5.4\%), Paraná (4\%), Piauí (4\%), Paraíba (PB) (3.5\%) and Pernambuco and MT ( $2.8 \%$ each). In the Amazon Region, the two states with the highest prevalence were AC, with $2.4 \%$ (possibly due to the migration of people with Chagas disease from northeastern Brazil) and AM, with $1.88 \%$, while the rate in PA was only $0.5 \%$. However, after analysing the data in greater detail, Silveira and Passos (1986) identified pockets of Chagas infection with rates higher than the national average. Among these, they highlighted Colares in PA, with 5.1\% and Barcelos, Novo Airão and Japurá in $\mathrm{AM}$, with $6.3 \%, 6.8 \%$ and $6.9 \%$, respectively.

After this national survey, several other studies were presented, including reports on acute outbreaks, case reports and reports on the prevalence and morbidity of Chagas disease in the Brazilian Amazon Region. Among these investigations, studies by Coura et al. (1993, 1994a, b, 1995a, b, 1999, 2002a, b), Valente and Valente (1993), Valente et al. (1994, 1998, 1999, 2000, 2009), Pinto et al. (2001, 2003, 2004, 2008), Albajar et al. (2003), Junqueira et al. (2005), Xavier et al. (2006) and Brum-Soares et al. (2010) can be highlighted.

In three preliminary serological surveys of 2,254 residents in the main settlement of the municipality of Barcelos (Coura et al. 1999) carried out in 1991, 1993 and 1997, we found a mean prevalence of Chagas disease of $13 \%$. However, serological tests using the confirmatory techniques of indirect immunofluorescence, conventional and recombinant ELISA and Western blotting (Tesa-blot) were only capable of confirming $2.8-5 \%$ as positive findings. A survey that we conducted recently using immunofluorescence of samples on filter paper from 4,880 residents of Barcelos showed that 221 individuals $(4.5 \%)$ presented strongly reactive serological tests, i.e., tests considered to be positive, while 302 individuals $(6.2 \%)$ presented weakly reactive serological tests, which were considered to be doubtful. We are currently collecting venous blood samples from the latter cases to obtain serological confirmation.
Risks of endemic Chagas disease in the Brazilian Amazon - The risks of endemicity of Chagas disease in the Brazilian Amazon Region are listed below according to Coura et al. (1993, 1994a, b, 1995a, b, 1999, 2002a, b), Anonymous (2005), Junqueira et al. (2005) and BrumSoares et al. (2010). These risks would be expected to be the same throughout Pan-Amazonia, although there will be features specific to each country. These risks are as follows. (i) There is an extensive reservoir of wild mammals infected with T. cruzi, represented in the Brazilian Amazon Region by 33 species in six orders, namely Marsupialia, Chiroptera, Rodentia, Edentada (Xenarthra), Carnivora and Primata (Table II). (ii) Out of the 27 species of triatomines recognised in Pan-Amazonia (Abad-Franch \& Monteiro 2007), 16 belong to the genera Belminus, Cavernicola, Eratyrus, Pantrogylus, Rhodnius and Triatoma, all of which have been found in the Brazilian Amazon Region (Coura et al. 2002a, b, Junqueira et al. 2005) and 10 of which (Table III) have been found to be infected with T. cruzi. (iii) There have been several outbreaks of acute Chagas disease transmitted via the ingestion of foods contaminated with the faeces and urine of triatomines or the scent secretions of marsupials in the Brazilian Amazon Region, particularly in PA, AP, MA and AC (Valente et al. 1999, 2009, Pinto et al. 2008) and, more recently, in AM. (iv) The uncontrolled deforestation in the Amazon Region with the concomitant reduction in the numbers and expulsion of the wild mammals that are the natural source of food for triatomines has stimulated pre-adaptation and adaptation of triatomines to human homes. (v) The increasing migration of people and their domestic animals from regions that are endemic for Chagas disease to the Amazon Region, which has been favoured through the opening of new highways, the construction of hydroelectric schemes, the exploration for oil and gas and other activities requiring labour, may promote the transfer of Chagas disease from endemic areas to the Amazon Region. Finally, (vi) the lack of knowledge about and the specific requirements for Chagas disease surveillance in the Amazon Region, as well as access difficulties and the predominance of plant gathering activities among the native population of this region, as mentioned earlier, constitute not only a future risk, but also the current reality of autochthonous disease in this region.

Domestic and peridomestic foci of vector populations have been described in different subregions of the Amazon Region. These foci include Triatoma maculata in rural and urban areas of RR, Panstrogylus geniculatus in peridomestic areas on the island of Marajó, PA (Valente et al. 1998), Rhodnius stali in Alto Beni, Bolivia, and Panstrogylus herreri in the Marañon valley, Peru. The presence of Rhodnius prolixus in the Orinoco region, which is located at the transition to the Amazon Region, is of concern (Aguilar et al. 2007). There are indications that domestication of T. maculata is occurring, in indigenous areas of the Amazon Region in TO. This finding is also of concern, given that T. maculata is an important vector in Venezuela.

Since Carlos Chagas (1924) confirmed that the parasite T. cruzi was present in isolates prepared by AbenAthar in 1922 from monkeys of the species Saimiri 
TABLE II

Mammals from Brazilian Amazon found infected with Trypanosoma cruzi

\begin{tabular}{|c|c|c|}
\hline Order & Species & References \\
\hline \multirow[t]{6}{*}{ Marsupialia (Didelphiomorphia) } & Calluromys spp & Lainson et al. (1979), Miles et al. (1981) \\
\hline & Didelphis marsupialis & $\begin{array}{l}\text { Rodrigues and Mello (1942), Deane (1961, 1964b), } \\
\text { Lainson et al. (1979), Miles et al. (1981), Póvoa et al. } \\
\text { (1984) }\end{array}$ \\
\hline & Marmosa cinerea & $\begin{array}{l}\text { Deane and Jansen (1939), Deane (1961), Lainson et al. } \\
\text { (1979), Póvoa et al. (1984) }\end{array}$ \\
\hline & Metachirus nudicaudatus & $\begin{array}{l}\text { Deane (1958), Lainson et al. (1979), Miles et al. } \\
\text { (1981), Póvoa et al. (1984) }\end{array}$ \\
\hline & Monodelphis brevicaudata & Miles et al. (1981), Póvoa et al. (1984) \\
\hline & Philander opossum & Deane (1958), Lainson et al. (1979), Miles et al. (1981) \\
\hline \multirow[t]{11}{*}{ Chiroptera (T. cruzi or T. cruzi-like) } & Carollia perspicillata & Dias et al. (1942) \\
\hline & Choeroniscus minor & Dias et al. (1942) \\
\hline & Glossophaga sorcina & Dias et al. (1942) \\
\hline & Lonchophylla mordax & Dias et al. (1942) \\
\hline & Mycronycteris megalotis & Dias et al. (1942) \\
\hline & Molossus major & Deane $(1961,1964 a)$ \\
\hline & Molossus ater & Deane (1961) \\
\hline & Phyllostomus hastatus & Deane $(1961,1964 a)$ \\
\hline & Plyllostomus alongatus & Dias et al. (1942) \\
\hline & Noctilio labialis & Dias et al. (1942) \\
\hline & Saccopterix bilineata & Dias et al. (1942) \\
\hline \multirow[t]{9}{*}{ Rodentia } & Agouti paca & Lainson et al. (1979) \\
\hline & Coendou spp & Lainson et al. (1979), Miles et al. (1981) \\
\hline & Dasyprocta spp & $\begin{array}{l}\text { Deane (1960), Lainson et al. (1979), Póvoa et al. } \\
\text { (1984) }\end{array}$ \\
\hline & Echymys chrysurus & Miles et al. (1981) \\
\hline & Nectomys squamipes & Deane (1960) \\
\hline & Oryzomys capito & Lainson et al. (1979), Póvoa et al. (1984) \\
\hline & Proechimys guayannensis & Deane (1961), Lainson et al. (1979) \\
\hline & Rattus rattus & Miles et al. (1981), Póvoa et al. (1984) \\
\hline & Sciurus spp & Miles et al. (1981), Póvoa et al. (1984) \\
\hline \multirow[t]{3}{*}{ Edentada (Xenarthra) } & Cyclopes ditactylus & Miles et al. (1981) \\
\hline & Dasypus novemcinctus & $\begin{array}{l}\text { Rodrigues and Mello (1942), Deane (1961, 1964a), } \\
\text { Lainson et al. (1979), Póvoa et al. (1984) }\end{array}$ \\
\hline & Tamandua tetradactyla & Rodrigues and Mello (1942) \\
\hline \multirow[t]{2}{*}{ Carnivora } & Nasua nasua & Lainson et al. (1979), Póvoa et al. (1984) \\
\hline & Tayra barbara & $\begin{array}{l}\text { Ferreira and Deane (1938), Rodrigues and Melo } \\
\text { (1942), Deane }(1961,1964 b)\end{array}$ \\
\hline \multirow[t]{6}{*}{ Primates } & Cebuella pigmea & Ziccardi et al. (2000) \\
\hline & Sanguinus fuscicollis weddelli & Ziccardi et al. (2000) \\
\hline & Sanguinus imperator imperator & Ziccardi et al. (2000) \\
\hline & Sanguinus midas niger & Miles et al. (1981) \\
\hline & Saimiri sciureus & $\begin{array}{l}\text { Chagas (1924), Deane (1964b), Ziccardi and } \\
\text { Lourenço-de-Oliveira (1997) }\end{array}$ \\
\hline & Saimiri ustus & Ziccardi and Lourenço-de-Oliveira (1997) \\
\hline
\end{tabular}

source: Coura et al. (2002b), Junqueira et al. (2005), Ziccardi and Lourenço-de-Oliveira (1997), Ziccardi et al. (2000). 
TABLE III

Triatomines from Brazilian Amazon found infected and not infected with Trypanosoma cruzi

\begin{tabular}{ll}
\hline $\begin{array}{l}\text { Species found infected } \\
\text { Eratyrus mucronatus }\end{array}$ & Lent and Wigodzinsky (1979), Miles et al. (1981) \\
$\begin{array}{l}\text { Microtriatoma trinidadensis } \\
\text { Panstrogylus geniculatus }\end{array}$ & $\begin{array}{l}\text { Miles et al. (1981) } \\
\text { Dias et al. (1942), Rodrigues and Mello (1942), Almeida (1971), Póvoa et al. (1984), Brazil et } \\
\text { al. (1985), Barrett and Guerreiro (1991) }\end{array}$ \\
Panstrogylus lignarius & $\begin{array}{l}\text { Deane and Damasceno (1949), Almeida (1971), Lainson et al. (1979), Lent and Wigodzinski } \\
\text { (1979), Miles et al. (1981), Póvoa et al. (1984), Brazil et al. (1985), Barrett and Guerrreiro (1991) }\end{array}$ \\
$\begin{array}{l}\text { Panstrogylus rufotuberculatus } \\
\text { Rhodnius brethesi }\end{array}$ & $\begin{array}{l}\text { Coura et al. (1999) } \\
\text { Rhodnius neglectus }\end{array}$ \\
$\begin{array}{l}\text { Rhodnius paraensis } \\
\text { Rhodnius pictipes }\end{array}$ & Bent and Wigodzinski (1979), Miles et al. (1981) \\
& Lent and Wigodzinski (1979), Rodrigues and Mello (1942), Almeida (1971), Lainson et al. \\
Rhodnius robustus & (1979), Miles et al. (1981), Póvoa et al. (1984), Brazil et al. (1985), Barrett and Guerreiro (1991) \\
Species found not infected & Lent and Wigodzinski (1979), Miles et al. (1981), Póvoa et al. (1984), Brazil et al. (1985) \\
Belminus herreri & \\
Cavernicola lenti & Miles et al. (1981) \\
Cavernicola pilosa & Barrett and Guerreiro (1991) \\
Rhodnius nasatus & Dias et al. (1942), Almeida (1971) \\
Triatoma maculata & Brazil et al. (1985), Rebello et al. (1998) \\
Triatoma rubrofasciata & Almeida (1971), Lent and Wigodzinski (1979), Barrett and Guerreiro (1991), Rebello et al. (1998) \\
& Lainson et al. (1979), Miles et al. (1981), Brazil et al. (1985), Rebello et al. (1998)
\end{tabular}

source: Coura et al. (2002), Junqueira et al. (2005).

sciureus, Chagas disease has been evolving from an enzootic disease of wild animals to an anthropozoonosis. The latter term denotes animal diseases that are transmitted to humans when they invade wild ecotopes or when animals penetrate human homes because of their proximity, as shown in Fig. 2. In some areas, such as in the middle and upper Negro River microregion, Chagas disease can be considered to be occupational and endemic because it is transmitted regularly and continually between individuals who gather piaçaba (a species of palm tree) material and their families. However, the constant epidemic outbreaks that have been occurring in different areas of the Amazon Region require a new surveillance and control strategy involving the training of technicians to achieve early diagnosis and the training of multipliers, especially elementary school teachers and healthcare agents to monitor the disease.

Morbidity of Chagas disease in the Brazilian Amazon - The clinical manifestations of acute Chagas disease in the Brazilian Amazon Region are generally severe, unrestrained and different in certain aspects from its manifestations in the classic areas where the disease occurs. We believe that the greater severity of the acute phase of the disease in the Brazilian Amazon Region is due to the transmission mechanism, which is oral in most cases. In such cases, the inoculum is almost always larger than in cases involving vector transmission. Borges-Pereira et al. (1988) demonstrated that the mean volume eliminated by a triatomine per defecation includes approxi- mately 140 parasites, while inocula received through oral transmission are believed to be much larger (Coura 2006). In the series of 233 cases studied by Pinto et al. (2008), fever was present in $100 \%$ of the patients, headache in $92.3 \%$, myalgia in $84.1 \%$, pallor in $67 \%$, dyspnea in $58.4 \%$, lower-limb oedema in $57.9 \%$, facial oedema in $57.5 \%$, abdominal pain in $44.2 \%$, myocarditis in $39.9 \%$ and exanthema in $27 \%$. In the present series, electrocardiographic abnormalities were present in $51.1 \%$. In the series by Pinto et al. (2008), attention was drawn to pericardial effusion, which was observed in $46.2 \%$ of the cases, with a general mortality rate of 5.6\%. Among the 13 individuals who died, in 10 cases $(76.9 \%)$, death was due to cardiovascular impairment. The main difference between their study and several others addressing the acute phase of Chagas disease in classical endemic areas was the severity of the disease. Two-thirds or more of the acute-form or initial cases in the classical endemic areas are asymptomatic or oligosymptomatic. However, Pinto et al. (2008) drew attention to facial oedema and the high percentage of exanthema in their sample, which are characteristics that are very specific for oral transmission (Fig. 3). Facial oedema most likely results from penetration of T. cruzi into the oral mucosa at the beginning of the infection and the high rate of exanthema results from the large size of the inoculum, thereby leading to dissemination of the parasite in the form of parasitic septicaemia. Similarly, myalgia and abdominal pain are caused by parasitic action on the skeletal musculature and digestive tract, respectively. These characteristics 


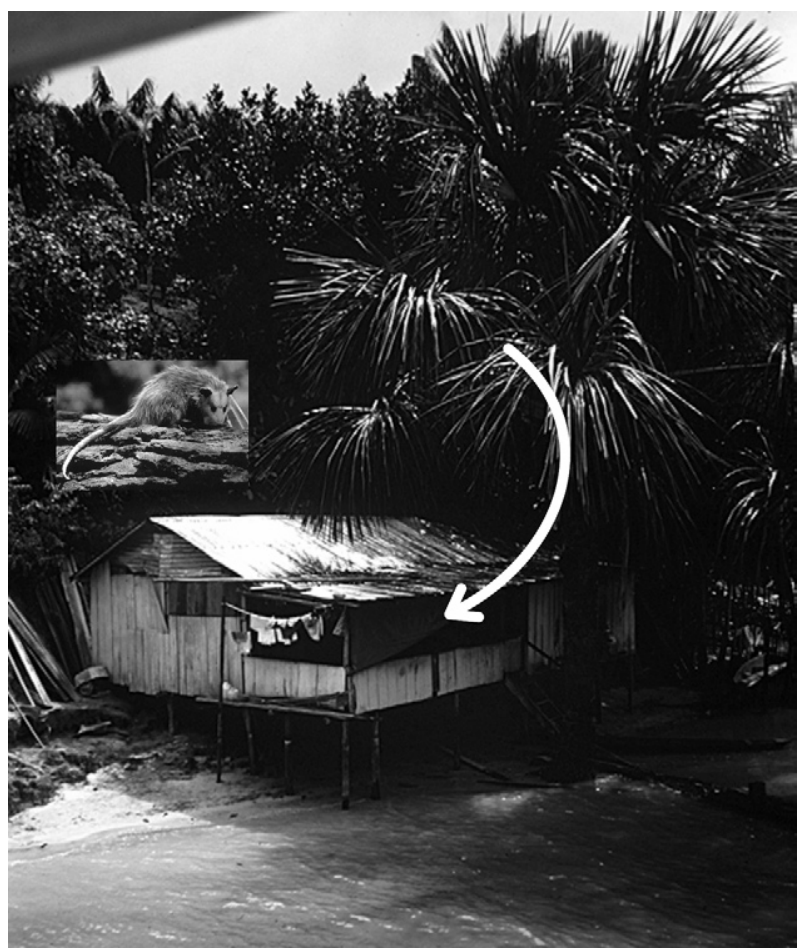

Fig. 2: palm trees habitat of triatomines and opossum infected with Trypanosoma cruzi invading huts in the Amazon Region.

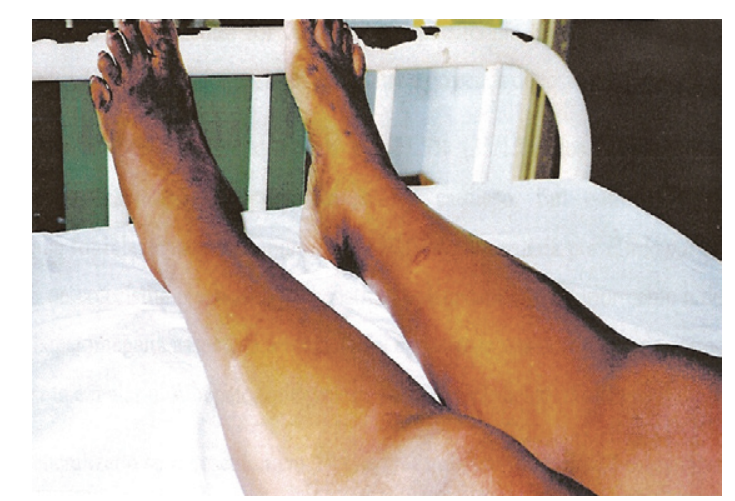

Fig. 3: severe exanthema in acute case of Chagas disease by oral transmission (Pinto et al. 2008).

are typical of outbreaks of acute Chagas disease that occur through oral transmission in the Brazilian Amazon Region and in several other regions of Brazil, such as in Catolé do Rocha in PB and Navegantes in Santa Catarina (Shikanai-Yasuda et al. 1991, Steindel et al. 2008, Shikanai-Yasuda \& Carvalho 2012).

The manifestations of the chronic phase of Chagas disease described in the Brazilian Amazon have been similar to those in other areas of Brazil, with the exception of "megas" (enlargement) of the oesophagus and of the colon. Megas either does not appear or is very rare in the Amazon Region, as is true in other countries located north of the Equator. Recently, Brum-Soares et al. (2010) carried out a seroepidemiological and clinical study in 152 individuals living in the municipality of Barcelos using an extensive epidemiological questionnaire and four serological tests: indirect immunofluorescence in serum, conventional and recombinant ELISA and Tesa-blot. Cases that were reactive in the indirect immunofluorescence test and positive in at least two other tests were considered to be positive, cases with only one reactive test or with very low titres were considered borderline and cases with four non-reactive tests were considered negative. Using this methodology, these researchers found 38 positive cases $(25 \%), 31$ borderline cases $(20.4 \%)$ and 83 negative cases $(54.6 \%)$. This epidemiological study showed that the activity of gathering material from the piaçaba was 10.4 times more frequent among seropositive individuals when compared to seronegative individuals and $86.7 \%$ of the cases recognised species belonging to the genus Rhodnius as the local vectors in piaçaba plantations. However, among seronegative individuals, only $34.2 \%$ recognised this vector. An analysis of age and sex-matched seropositive and seronegative individuals showed that there were electrocardiographic abnormalities in $36.8 \%$ of the seropositive individuals, but only $18.4 \%$ of the seronegative individuals. Precordialgia and palpitations occurred more frequently among seropositive individuals. Clinical analysis of the digestive tract and radiological evaluation of the oesophagus in 29 pairs of individuals (seropositive and seronegative) did not show any significant changes. A previous study conducted in the same region by Albajar et al. (2003) showed that there was a direct relationship between seropositivity, the frequency of performing piaçaba gathering activities and the presentation of clinical, electrocardiographic and echocardiographic manifestations. Albajar et al. (2003) also described two fatal cases of dilated myocardiopathy due to chronic Chagas infection in which the heart radiography and electrocardiogram findings were typical of the disease. One case was proven to be an infection caused by $T$. cruzi using histopathology and in situ polymerase chain reaction. Subsequently, Xavier et al. (2006) reported three new cases typical of chronic Chagas myocardiopathy proven using serological, clinical, radiographic, electrocardiographic and echocardiographic examinations. Two of these cases died, one after two years and one after three.

Intergovernmental initiative for the surveillance and prevention of Chagas disease in the Amazon Region (AM$C H A$ ) - A preliminary meeting was held under the auspices of Economic Latin America Net Work on Genetics and Control of Triatomines from 30 July-2 August 2002 under the direction of Dr Christopher Schofield. Many researchers from Brazil and several other South American countries participated in this meeting, which was coordinated by Prof Felipe Guhl in Palmarí, in the municipality of Tabatinga on the Solimões River, Brazil, at the border with the Colombian municipality of Leticia.

At this meeting, the participants discussed the problems of Chagas disease in Pan-Amazonia and the need to create an intergovernmental initiative involving the nine countries with territory in the Amazon Region for 
the purpose of surveillance and prevention of the disease in these countries. The participants suggested that a new meeting to be organised by the Pan-American Health Organization (PAHO) should be held to create AMCHA. This meeting was duly held in Manaus, AM from 19-22 September 2004.

The meeting in Manaus had the following objectives (Anonymous 2005): (i) assessment of the risk that endemic Chagas disease might become established in the Amazon Region, (ii) determination of the research needed for the surveillance and prevention of Chagas disease in the Amazon Region, (iii) proposals for achieving surveillance and prevention of Chagas disease in this region and (iv) proposals for a system of international cooperation for the surveillance and prevention of Chagas disease in the Amazon Region (AMCHA). This meeting, promoted by PAHO, was attended by representatives from all nine countries in the Amazon Region. In addition to the official representatives of these countries, more than 90 researchers from the different countries in the Amazon Region took part, including the President of the Brazilian National Research Council, Prof Erney Plesmann Camargo. The participants held detailed discussions about the problems of Chagas disease in the region, the objectives of AMCHA and the way in which the organisation would be brought into operation.

Three additional meetings were held: in Cayenne, French Guiana, from 2-4 November 2005, in Quito, Ecuador, from 18-20 September 2006, and in Caracas, Venezuela, from 28-30 October 2008. However, despite recognising the risk that Chagas disease might become endemic in the Amazon Region, the need to increase research in the region and to increase understanding of the endemic disease, the various proposals regarding the surveillance and prevention of the disease and the great efforts exerted by PAHO, very little concrete action was achieved. It is hoped that at the next meeting to be held with INCOSUR (Southern Cone Initiative to Control/ Eliminate Chagas Disease) in Bolivia in 2012, we may be able to increase international cooperation regarding the surveillance and prevention of Chagas disease in Pan-Amazonia and that the AMCHA initiative can fulfil the objectives that were proposed at the founding meeting in September 2004, held in Manaus, in the Brazilian Amazon Region. An overview discussion addressing the INCOSUR in the Americas and non-endemic countries was held in Brazil (Coura et al. 2009).

Perspectives regarding the control of Chagas disease in the Amazon - The majority of acute cases of Chagas disease in the Amazon Region are caused by outbreaks occurring via oral transmission (Pinto et al. 2008). Vector transmission is almost always connected with plant gathering activities, particularly from piaçaba palm trees (Coura et al. 1999, 2002a, b, Brum-Soares et al. 2010), or through accidental contact when people go into the forest for various reasons. Transmission can also occur when vectors and wild animals (marsupials) invade human homes in search of food. Considering these factors, the methods for the prevention and control of Chagas disease in the Amazon Region are necessarily different from the techniques applied in the classical endemic areas, where the vectors are domesticated and transmission occurs continually (Dias et al. 2002). In the classic endemic areas where the vectors have become adapted to homes, as is the case for Triatoma infestans in some countries in South America and R. prolixus in Central America and some Andean countries, use of residual insecticides in and around people's homes is essential. In the Amazon Region, where there has been no vector adaptation, with the exception of the instances mentioned earlier, it is of fundamental importance to train technicians to achieve early diagnosis and treatment of acute cases. For triatomines to be recognised as a part of epidemiological surveillance, it is essential for a large amount of information to be made available to the population through posters, radio, television and the actions of healthcare agents and elementary school teachers as well as through courses and seminars to train surveillance multipliers.

Training for healthcare technicians - Training for laboratory technicians aimed at early diagnosis of acute cases of the disease and recognition of triatomines is of fundamental importance for epidemiological surveillance. Likewise, there should be training for doctors and nurses focused on the clinical diagnosis and treatment of acute and chronic cases of Chagas disease and on controlling the disease in the Amazon Region.

Our research group has gained experience holding training courses for malaria microscopists and laboratory technicians within the public healthcare system to provide them with the skills to detect $T$. cruzi during routine tests for diagnosing malaria. The techniques taught in these courses have included using hemograms and direct investigation of $T$. cruzi in fresh blood tests or stained thick smear tests in suspected cases of Chagas infection along with recognition of triatomines and examination of their faeces to detect $T$. cruzi. These experiences have been of major importance for the surveillance of Chagas disease in the Brazilian Amazon Region. Courses held in the nine Brazilian states of the Amazon Region with support from Médecins Sans Frontières between 20062008 have been of fundamental importance in detecting acute cases of the disease in this region. Since that time, 100-150 cases have been reported every year. Of course, this is only a small proportion of the cases that actually occur, given that the majority of the individuals with the disease do not seek the public healthcare and hospital services available in the region. The true occurrence rate will certainly be 10-20 times higher. However, many acute outbreaks of the disease have been identified in the region, due in part to the dissemination of information about the disease. Because of these courses, a training manual for technicians addressing how to detect $T$. cruzi was prepared with funding from PAHO through the World Health Organization (WHO) Chagas disease program. This training manual has been revised to produce a second edition on Chagas disease for wide distribution in the Brazilian Amazon Region. A Spanish edition of this manual is under preparation for distribution in Spanish-language countries. 
The course and the manual were first prepared by Junqueira et al. (2009) and many collaborators, with the second revised edition (2010-2011) being funded by the Chagas Disease Ecoepidemiology Project for the Amazon Region, Department of Science and Technology/Ministry of Health and National Council for the Scientific and Technological Development through the Neglected Diseases Program of PAHO/WHO with coordination by the Parasitic Diseases and Tropical Medicine Laboratory of the Oswaldo Cruz Institute/Oswaldo Cruz Foundation. The manual presents the following modular structure: Modules I and II were administered together during the afternoons of five working days in one week with the aim of not disrupting the technicians' routine activities. The same approach was used for Module III (Junqueira et al. 2009).

Based on the experience accumulated from the 12 courses presented in the Brazilian Amazon Region, we are certain that this course model will have the same success in the other countries of the Amazon Region.

Training for elementary school teachers and healthcare agents as multipliers - Training elementary school teachers and healthcare agents as multipliers is of fundamental importance for the surveillance of Chagas disease and other vector-transmitted diseases in the Amazon Region. Teachers have access to all children and children have a special curiosity for natural phenomena and are very good at spotting vectors such as triatomines in areas surrounding their homes and inside their homes, even in areas where plant material is being gathered, such as in the piaçaba plantations of the Negro River region in AM. Similarly, healthcare agents are an important link between communities and regional healthcare centres and they may play a prominent role not only in providing primary care, but also in health promotion through education of families, including by showing them examples of the vectors and asking people to catch them and take them to the regional centres for identification and investigation of whether they are infected with T. cruzi.

In 2008, a pilot course on Chagas disease and malaria was conducted for 46 elementary school teachers, with priority given to teachers working in the rural zone of the municipality of Barcelos, in the Negro River microregion of AM. The duration of the course was $40 \mathrm{~h}$ (1 week, full time) and was characterised by simple language and considerable use of images, focusing on the biomedical and social factors involved in the transmission and maintenance of the diseases. The process included workshops and practical classes designed to guide the teachers toward understanding pedagogical possibilities for introducing these topics into the school curriculum through approaches that would be appropriate for the students' different age groups and in accordance with the local realities faced by each teacher. A questionnaire that had previously been validated was applied before and after the course to investigate the changes in knowledge that had been promoted through this educational process, followed by quantitative and qualitative analyses.

It was found that the teachers had little knowledge (before the course) regarding the transmission mechanisms, prevention methods and ways in which the dis- eases were associated with their vectors. An assessment of knowledge about Chagas disease is being planned for implementation in 2011/2012.

In the preliminary evaluation of knowledge about malaria (Suarez-Mutis et al. 2011), all of the teachers had "heard of" the disease, but only $48.3 \%$ of them correctly recognised the classic trio of symptoms of the disease (shivering, fever and sweating). In the test after the course, $82.6 \%$ were able to provide a correct response. In assessing the transmission mechanisms of the infection in the pretest, only $50 \%$ provided generally correct information, albeit confusing malaria with dengue, while $73.3 \%$ gave the correct response in the test after the course. In relation to measures for avoiding malaria, $19 \%$ presented a correct response after the course. Finally, considering the lack of knowledge of Chagas disease in the region, unlike the case for malaria, which is widely known, we believe that a lack of awareness of Chagas disease will be more evident given the difference in its vectors and transmission mechanisms and the low level of previous knowledge about the disease and its clinical manifestations in the region.

\section{REFERENCES}

Abad-Franch F, Monteiro FA 2007. Biogeography and evolution of Amazonian triatomiones (Hemiptera: Reduviidae): implications for Chagas disease surveillance in humid forest ecoregions. Mem Inst Oswaldo Cruz 102 (Suppl. I): 57-69.

Aguilar HM, Abad-Franch F, Dias JCP, Junqueira ACV, Coura JR 2007. Chagas disease in the Amazon Region. Mem Inst Oswaldo Cruz 102 (Suppl I): 47-55.

Albajar PV, Laredo SV, Terrazas MB, Coura JR 2003. Miocardiopatia dilatada em pacientes com infecção chagásica crônica. Relato de dois casos fatais autóctones do Rio Negro, estado do Amazonas. Rev Soc Bras Med Trop 36: 401-407.

Almeida FB 1971. Triatomíneos da Amazônia. Encontro de três espécies naturalmente infectadas por Trypanosoma semelhante ao cruzi, no estado do Amazonas (Hemiptera: Reduviidae). Acta Amaz (Manaus) 1: 89-93.

Anonymous 2005. Reunião Intergovernamental sobre Vigilância e Prevenção da Doença de Chagas na Amazônia. Implementação da Iniciativa Governamental de Vigilância e Prevenção da Doença de Chagas na Amazônia. Rev Soc Bras Med Trop 38: 52-89.

Barret TV, Guerreiro JCH 1991. Os triatomíneos (Hemiptera: Reduviidae) em relação à doença de Chagas na Amazônia. In AL Val, R Figluolo, E Feldberg (eds.), Bases cientificas para estratégia de preservação e desenvolvimento da Amazônia: fatos e perspectivas, INPA, Manaus, p. 119-130.

Barretto MP 1964. Reservatórios de Trypanosoma cruzi nas Américas. Rev Bras Malar 16: 527-552.

Barretto MP 1967. Estudo sobre reservatórios e vetores do Trypanosoma cruzi, XXII. Modificações de focos naturais da tripanosomíase americana e suas consequências. Rev Soc Bras Med Trop 1: 167-173.

Borges-Pereira J, Pessoa I, Coura JR 1988. Observações sobre as dejeções e o número de T. cruzi eliminados por diferentes espécies de triatomíneos durante a alimentação. Mem Inst Oswaldo Cruz 83 (Suppl. I): 7.

Branco SM 1990. Desafios amazônicos, 6th ed., Editora Moderna, São Paulo, 103 pp. 
Brazil RP, Silva AR, Albarelli A, Vale JF 1985. Distribuição e infecção de triatomíneos por Trypanosoma do tipo cruzi na Ilha de São Luis, Maranhão. Rev Soc Bras Med Trop 18: 257-260.

Brum-Soares LM, Xavier SS, Sousa AS, Pereira JB, Ferreira JMBB, Costa IR, Junqueira ACV, Coura JR 2010. Morbidade da doença de Chagas em pacientes autóctones da microrregião do Rio Negro, estado do Amazonas. Rev Soc Med Trop 43: 170-177.

Camargo ME, Silva GR, Castilho EA, Silveira AC 1984. Inquérito sorológico da prevalência da infecção chagásica no Brasil, 19751980. Rev Inst Med Trop Sao Paulo 26: 192-204.

Castro T 1998. Problemática geopolítica. In Amazonia. Atualidades e perspectivas, Anais do I Seminário do Projeto SIVAM, Ministério da Aeronáutica, Rio de Janeiro, p. 115-191.

Chagas C 1924. Infection naturelle dês singes du Pará (Chrysotrix sciureus) par Trypanosoma cruzi. Comp Rend Seanc Soc Biol Ses Fin 90: 873-876.

Coura JR 1988. Determinantes epidemiológicos da doença de Chagas no Brasil: a infecção, a doença e sua morbi-mortalidade. Mem Inst Oswaldo Cruz 83: 392-402.

Coura JR 2006. Transmissão da infecção chagásica por via oral na história natural da doença de Chagas. Rev Soc Bras de Med Trop 39 (Suppl. IV): 113-117.

Coura JR 2007. Chagas disease: what is known what is need - A background article. Mem Inst Oswaldo Cruz 102 (Suppl. I): 113-122.

Coura JR, Abad-Franch F, Aguillera X, Dias JCP, Gil H, Junqueira ACV, Lima JF, Moreira JCC, Schall V, Schmunis G 2009. The inciative for the control of Chagas disease in the Americas and in non-endemic countries. Rev Soc Bras Med Trop 42 (Suppl. II): 106-110.

Coura JR, Arboleda Naranjo M, Willcox HPF 1993. Doença de Chagas na Amazônia brasileira. Rev Soc Bras Med Trop 26 (Suppl. 2): $15-17$.

Coura JR, Arboleda Naranjo M, Willcox HPF 1995a. Chagas disease in the Brazilian Amazon. II. A serological survey. Rev Inst Med Trop Sao Paulo 37: 103-107.

Coura JR, Barrett TV, Arboleda Naranjo M 1994a. Ataque de populações humanas por triatomíneos silvestres no Amazonas: uma nova forma de transmissão da infecção chagásica? Rev Soc Bras Med Trop 27: 251-253.

Coura JR, Dias JCP 2009. Epidemiology, control and surveillance of Chagas disease: 100 years after its discovery. Mem Inst Oswaldo Cruz 104 (Suppl. I): 21-40.

Coura JR, Junqueira ACV, Boia MN, Fernandes O 1999. Chagas disease: from bush to huts and houses. Is it the case of the Brazilian Amazon? Mem Inst Oswaldo Cruz 94 (Suppl. I): 379-384.

Coura JR, Junqueira ACV, Boia MN, Fernandes O, Bonfante C, Campos JE, Santos L, Devera R 2002a. Chagas disease in the Brazilian Amazon. IV. A new cross-sectional study. Rev Inst Med Trop Sao Paulo 44: 159-165.

Coura JR, Junqueira ACV, Carvalho-Moreira CJ, Borges-Pereira J, Albajar PV 2007. Uma visão sistêmica da endemia chagásica. In AC Silveira, La enfermedad de Chagas a la puerta de los 100 años del conocimiento de una endemia americana ancestral, Org Panam Salud y Fundación Mundo Sano, Buenos Aires, p. 23-35.

Coura JR, Junqueira ACV, Fernandes O, Valente SAS, Miles MA 2002b. Emerging Chagas disease in Amazonian Brazil. Trends Parasitol 18: 171-176.

Coura JR, Junqueira ACV, Giordano CM, Funatsu RK 1994b. Chagas disease in the Brazilian Amazon. I. A short review. Rev Inst Med Trop Sao Paulo 36: 363-368.
Coura JR, Willcox HPF, Arboleda Naranjo M, Fernandes O, Paiva DD 1995b. Chagas disease in the Brazilian Amazon. III. A crosssectional study. Rev Inst Med Trop Sao Paulo 37: 415-420.

Deane LM 1958. Novo hospedeiro de tripanossomos dos tipos T. cruzi e T. rangeli encontrados no estado do Pará: o marsupial Metachirops opossum opossum. Rev Bras Malar 10: 531-541.

Deane LM 1960. Sobre um tripanossoma do tipo T. cruzi encontrado em rato silvestre no estado do Pará. Rev Bras Malar 12: 87-102.

Deane LM 1961. Tripanossomídeos de mamíferos da região Amazônica. I. Alguns flagelados encontrados no sangue dos mamíferos silvestres do estado do Pará. Rev Inst Med Trop Sao Paulo 3: 15-28.

Deane LM 1964a. Animal reservoirs of Trypanosoma cruzi in Brazil. Rev Bras Malar 6: 27-48.

Deane LM 1964b. Tripanossomídeos de mamíferos da região Amazônica. III. Hemoscopia e xenodiagnóstico de animais silvestres dos arredores de Belém, Pará. Rev Inst Med Trop Sao Paulo: 225-232.

Deane LM 1967. Tripanossomídeos de mamíferos da Região Amazônica. IV. Hemoscopia e xenodiagnóstico de animais silvestres da estrada Belém-Brasília. Rev Inst Med Trop Sao Paulo 9: 143-148.

Deane MP, Damasceno R 1949. Encontro de Panstrongylus lignarius naturalmente infectado por Trypanosoma do tipo cruzi e algumas notas sobre a sua biologia. Rev Serv Saude Publica (Rio de Janeiro) 2: 809-814.

Deane LM, Damasceno RG 1961. Tripanossomídeos de mamíferos da Região Amazônica. II. Tripanossomas de macacos da zona do Salgado, estado do Pará. Rev Inst Med Trop Sao Paulo 3: 61-70.

Deane LM, Jansen G 1939. Encontro do Schizotrypanum cruzi (Chagas, 1909) em marsupiais da espécie Marmosa cinerea Desmarest. Brasil-Med 5: 265-266.

Deane MP, Lenzi HL, Jansen AM 1984. Trypanosoma cruzi: vertebrate and invertebrate cycles in the same mammal host, the opossum Didelphis marsupialis. Mem Inst Oswaldo Cruz 79 (Suppl. I): 513-515.

Dias E, Mello GB, Costa O, Damasceno R, Azevedo M 1942. Investigações sobre esquizotripanose de morcegos no estado do Pará. Encontro de barbeiro Cavernicola pilosa como transmissor. Rev Bras Biol 2: 103-110.

Dias JCP, Prata A, Schofield CJ 2002. Doença de Chagas na Amazônia: esboço da situação atual e perspectivas de prevenção. Rev Soc Bras Med Trop 35: 669-678.

Ferreira LC, Deane LM 1938. Novo depositário silvestre do Schizotrypanum cruzi (Chagas 1909): a Irára, Toyra barbara. Brasil Med 52: $1159-1161$.

Floch H, Camain R 1948. Deux nouveaux cas de maladie de Chagas en Guyane Française. Bull Soc Path Exot 47: 22-25.

Floch H, Tasque P 1941. Un cas de maladie de Chagas en Guyane Française. Bull Soc Path Exot 40: 36-37.

Junqueira ACV, Albajar PV, Coura JR 2005. Enfermedad de Chagas en la Amazonia brasileña. In F Guhl, Primer Taller Internacional sobre Control de la Enfermedad de Chagas, Universidad de los Andes, Bogotá, p. 277-287.

Junqueira ACV, Gonçalves TCM, Moreira CJC 2009. Curso de capacitação dos microscopistas de malária e dos laboratoristas da rede pública da detecção do Trypanosoma cruzi, Imprenta Gómez y Tricotti SRL, Montevideu, 208 pp.

Lainson R, Shaw JJ, Frahia H, Miles MA, Draper CC 1979. Chagas disease in the Amazon Basil. I. Trypanosoma cruzi in silvatic mammals, triatomine bugs and man in the state of Pará, North Brazil. Trans R Soc Trop Med Hyg 73: 193-204. 
Laranja FS, Dias E, Nobrega G, Miranda A 1956. Chagas disease. A clinical, epidemiologic and pathologic study. Circulation 14: 1035-1060.

Lent H, Wygodzinsky P 1979. Revision of triatominaes (Hemiptera: Reduviidae) and their significance as vectors of Chagas disease. Bull Am Mus Nat History 63: 125-520.

Miles MA, Souza AA, Póvoa M 1981. Chagas disease in the Amazon Basin. III. Ecotopes of ten triatomine bug species (Hemiptera: Reduviidae) from the vicinity of Belém, Pará state, Brazil. J Med Entomol 18: 266-278.

Pinto AYN, Harada GB, Valente VC, Abud JEA, Gomes FS, Souza GSR, Valente SAS 2001. Acometimento cardíaco em pacientes com doença de Chagas aguda em microepidemia familiar, em Abaetuba, na Amazônia brasileira. Rev Soc Bras Med Trop 34: 413-419.

Pinto AYN, Valente SAS, Lopes R, Silva O, Castro T, Valente VC 2003. Ocorrência de tripanosomíase aguda familiar no município Igarapé-Mirim, Pará: gravidade de apresentação clínica em idosos. Rev Soc Bras Med Trop 36 (Suppl. I): 381.

Pinto AY, Valente SAS, Valente VC 2004. Emerging acute Chagas disease in Amazonian Brazil: cases reports with serious cardiac involvement. Braz J Infect Dis 8: 454-460.

Pinto AYN, Valente SAS, Valente VC, Ferreira-Junior AG, Coura JR 2008. Fase aguda da doença de Chagas na Amazônia brasileira. Estudo de 233 casos do Pará, Amapá e Maranhão observados entre 1988 e 2005. Rev Soc Bras Med Trop 41: 602-614.

Póvoa MM, de Souza AA, Naiff RD, Arias JR, Naiff MF, Viancrdi CB, Miles MA 1984. Chagas disease in Amazon basin IV. Host records of Trypanosoma cruzi zymodemes in the states of Amazon and Rondônia, Brazil. Ann Trop Med Parasitol 78: 479-487.

Rebelo JM, Barros VLL, Mendes WA 1998. Espécies de triatominae (Hemiptera: Reduviidae) do estado do Maranhão, Brasil. Cad Saude Publica (Rio de Janeiro) 14: 187-192.

Rodrigues BA, Mello GB 1942. Contribuição ao estudo da tripanossomíase americana. Mem Inst Oswaldo Cruz 37: 77-90.

Shaw J, Lainson R, Fraiha H 1969. Considerações sobre a epidemiologia dos primeiros casos autóctones de doença de Chagas registrados em Belém, Pará, Brasil. Rev Saude Publica 3: 153-157.

Shikanai-Yasuda MA, Carvalho NB 2012. Oral transmission of Chagas disease. Clin Infect Dis 54: doi: 10.1093/cid/cir956.

Shikanai-Yasuda MA, Marcondes CB, Guedes AL, Siqueira GS, Barone AA, Dias JCP, Amato Neto V, Tolezano JE, Peres BA, Arruda ER, Lopes MH, Shiroma M, Chapadeiro E 1991. Possible oral transmission of acute Chagas disease. Rev Inst Med Trop Sao Paulo 33: 355-381.
Silveira AC, Passos ADC 1986. Altos índices de prevalência sorológica de infecção chagásica em área da Amazônia. Rev Soc Bras Med Trop 19 (Suppl.): 45.

Steindel M, Pacheco LK, Scholl D, Soares MM, Milene H, Eger I, Kosmann C, Sincero TCM, Stoco PH, Murta SMF, Carvalhopinto CJ, Grisard EC 2008. Characterization of Tripanosoma cruzi, isolated from humans, vector and animal reservoir following an outbreaks of acute Chagas disease in Santa Catarina state, Brazil. Diag Microbiol Infect Dis 60: 25-32.

Suarez-Mutis MC, Coura JR, Massara C, Schall V 2011. Efeito da ação educativa no conhecimento de profesores do ensino básico sobre malária. Rev Saude Publica 45: 1-7.

Valente SAS, Valente VC 1993. Situação atual da doença de Chagas na Amazônia. Rev Soc Bras Med Trop 26 (Suppl. 2): 68-70.

Valente SAS, Valente VC, Ferreira SM, Santos TCM, Moura E, Uchoa AD 1994. Registro de doença de Chagas aguda em Sena Madureira, estado do Acre. Rev Soc Bras Med Trop 27 (Suppl. 1): 169.

Valente SAS, Valente VC, Fraiha Neto H 1999. Considerations on the epidemiology and transmission of Chagas disease in the Brazilian Amazon. Mem Inst Oswaldo Cruz 94 (Suppl. I): 395-398.

Valente SAS, Valente VC, Pinto AYN, César MJR, dos Santos MP, Miranda COS, Cuervo P, Fernandes O 2009. Analysis of an acute Chagas disease outbreak in the Brazilian Amazon: human cases, triatomines, reservoir mammals and parasites. Trans Roy Soc Trop Med Hyg 103: 291-297.

Valente SAS, Valente VC, Pinto AYN, Fraiha Neto H 2000. Microepidemia familiar e transmissão oral da doença de Chagas na Amazônia brasileira. Mem Inst Oswaldo Cruz 95 (Suppl. II): 69-72.

Valente VC, Valente SAS, Noireau F, Carrasco HJ, Miles MA 1998. Chagas disease in the Amazon Basin: association of Panstrongylus geniculatus (Hemiptera: Reduviidae) with domestic pigs. J Med Entomol 35: 99-103.

Xavier SS, Souza AS, Albajar PV, Junqueira ACV, Boia MN, Coura JR 2006. Cardiopatia chagásica crônica no Rio Negro, estado do Amazonas. Relato de três novos casos autóctones, comprovados por exames sorológicos, clínicos, radiográficos do tórax, eletro e ecocardiográficos. Rev Soc Bras Med Trop 39: 211-216.

Ziccardi M, Lourenço-de-Oliveira R 1997. The infection rates of trypanosomes in squirrel monkeys at two sites in the Brazilian Amazon. Mem Inst Oswado Cruz 92: 465-470.

Ziccardi M, Lourenço-de-Oliveira R, Lainson R, Brígido MCO, Muniz JAPC 2000. Trypanosomes of non-human primates from the National Centre of Primates, Ananindeua, State of Pará, Brazil. Mem Inst Oswado Cruz 95: 157-159. 